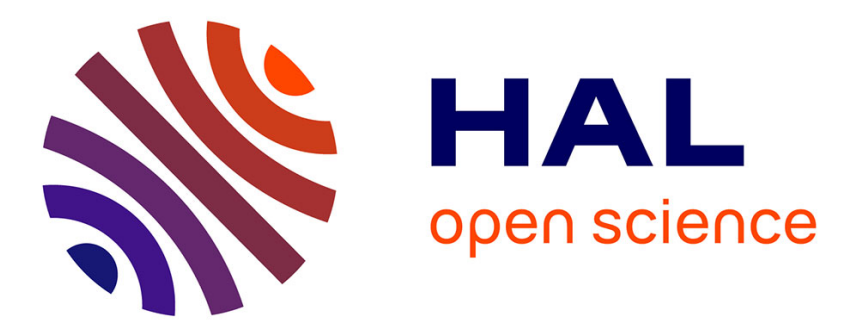

\title{
Effect of exposure to benzo[a]pyrene on SODs, CYP1A1/1A2- and CYP2E1 immunopositive proteins in the blood clam
}

\author{
M. Monari, O Cattani, G.P. Serrazanetti, A. Selli, G. Pagliuca, E. Zironi, \\ S.C.M. O'Hara, D.R. Livingstone
}

\section{To cite this version:}

M. Monari, O Cattani, G.P. Serrazanetti, A. Selli, G. Pagliuca, et al.. Effect of exposure to benzo[a]pyrene on SODs, CYP1A1/1A2- and CYP2E1 immunopositive proteins in the blood clam. Marine Environmental Research, 2007, 63 (3), pp.200. 10.1016/j.marenvres.2006.08.004 . hal00501887

\section{HAL Id: hal-00501887 \\ https://hal.science/hal-00501887}

Submitted on 13 Jul 2010

HAL is a multi-disciplinary open access archive for the deposit and dissemination of scientific research documents, whether they are published or not. The documents may come from teaching and research institutions in France or abroad, or from public or private research centers.
L'archive ouverte pluridisciplinaire HAL, est destinée au dépôt et à la diffusion de documents scientifiques de niveau recherche, publiés ou non, émanant des établissements d'enseignement et de recherche français ou étrangers, des laboratoires publics ou privés. 


\section{Accepted Manuscript}

Effect of exposure to benzo[a]pyrene on SODs, CYP1A1/1A2- and CYP2E1 immunopositive proteins in the blood clam Scapharca inaequivalvis

M. Monari, O Cattani, G.P. Serrazanetti, A. Selli, G. Pagliuca, E. Zironi, S.C.M. O'Hara, D.R. Livingstone

PII:

S0141-1136(06)00177-2

DOI: 10.1016/j.marenvres.2006.08.004

Reference: MERE 3066

To appear in:

Marine Environmental Research

Received Date:

3 May 2006

Revised Date: 28 August 2006

Accepted Date:

31 August 2006

Please cite this article as: Monari, M., Cattani, O., Serrazanetti, G.P., Selli, A., Pagliuca, G., Zironi, E., O’Hara, S.C.M., Livingstone, D.R., Effect of exposure to benzo[a]pyrene on SODs, CYP1A1/1A2- and CYP2E1 immunopositive proteins in the blood clam Scapharca inaequivalvis, Marine Environmental Research (2006), doi: 10.1016/j.marenvres.2006.08.004

This is a PDF file of an unedited manuscript that has been accepted for publication. As a service to our customers we are providing this early version of the manuscript. The manuscript will undergo copyediting, typesetting, and review of the resulting proof before it is published in its final form. Please note that during the production process errors may be discovered which could affect the content, and all legal disclaimers that apply to the journal pertain. 


\section{Effect of exposure to benzo[a]pyrene on SODs, CYP1A1/1A2- and CYP2E1 immunopositive proteins in the blood clam Scapharca inaequivalvis}

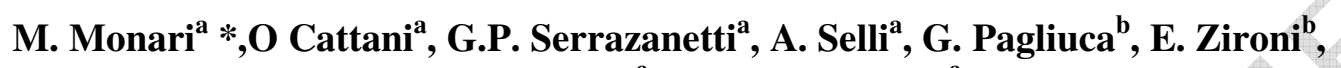
S.C.M. O'Hara ${ }^{\mathfrak{c}}$, D.R. Livingstone ${ }^{\mathrm{c}}$

Address: "Department of Biochemistry "G. Moruzzi", University of Bologna, Via Tolara di Sopra 50, 40064

Ozzano Emilia, Bologna (Italy)

${ }^{b}$ Department of Veterinary Public Health and Animal Pathology, University of Bologna, Via Tolara di Sopra 50, 40064 Ozzano Emilia, Bologna (Italy)

${ }^{c}$ Marine Biological Association of the UK Laboratory, Citadel Hill, Plymouth, Devon PL1 2PB, (UK)

*Corresponding author:

Marta Monari

Dipartimento di Biochimica "G. Moruzzi”,

Sezione Biochimica Veterinaria, Facoltà Medicina Veterinaria,

Università di Bologna, Via Tolara di Sopra, 50, 40064,

Ozzano Emilia, Bologna.

e-mail:mmonari@vet.unibo.it

Tel: +39-051-2097028/2097008

Fax: +39-051-2097037 


\section{Abstract}

The effects of water-borne exposure to benzo[a]pyrene (36 hrs; celite-bound $\left.0.44 \mathrm{mg} \mathrm{L}^{-1} \mathrm{~B}[\mathrm{a}] \mathrm{P}\right)$ on cytochrome P450 (CYP) and superoxide dismutases (SODs) were examined in digestive gland of the blood clam, Scapharca inaequivalvis. B[a]P accumulation and elimination were rapid, with maximum whole-body concentrations of $1.78 \mathrm{ng} \mathrm{g}^{-1}$ wet wt. after 12 hours of treatment, followed by a progressive decline to $0.89 \mathrm{ng} \mathrm{g}^{-1}$ at 36 hours. The presence of $\mathrm{B}[\mathrm{a}] \mathrm{P}$ resulted in an increase in total CYP of digestive gland microsomes from $54 \pm 14$ to $108 \pm 21 \mathrm{pmol} \mathrm{mg}^{-1}$ protein (mean $\pm \mathrm{SD}$; $\mathrm{p}<0.05,24 \mathrm{hrs})$. Increases were also seen in microsomal CYP1A1/1A2-immunopositive protein (50.5 kDa app. mol. wt; $\mathrm{p}<0.05$ ), but not CYP2E1-immunopositive protein (49 kDa app. mol. wt.), indicating a specific response of the former isoform. Exposure to $\mathrm{B}[\mathrm{a}] \mathrm{P}$ produced a steady increase in Mn-SOD digestive gland activity $(\mathrm{p}<0.01 ; \mathrm{p}<0.05)$ but no significant change in $\mathrm{Cu} / \mathrm{Zn}-\mathrm{SOD}$ activity. The respective proteins, measured by western blotting, weren't significant induced after $\mathrm{B}[\mathrm{a}] \mathrm{P}$ exposure.

$\mathrm{Cu} / \mathrm{Zn}-\mathrm{SOD}$ and $\mathrm{Mn}-\mathrm{SOD}$ activities were correlated with total CYP levels $(\mathrm{r}=0.96$ and 0.63 , respectively), indicating a role for CYP in reactive oxygen species (ROS) production during exposure. Both 'NADPH-independent' and NADPH-dependent metabolism of B[a]P by digestive gland microsomes was seen, producing mainly 1,6-, 3,6- and 6,12-diones, with some phenols and 7,8-dihydrodiol; putative protein adducts were also formed. Redox cycling of the diones may also have contributed to ROS production, leading to the increased SOD activities.

\section{Keywords:}

Benzo[a]pyrene metabolism, cytochrome P450, CYP1A1/1A2- and CYP2E1-immunopositive proteins, SOD isoforms, Scapharca inaequivalvis, digestive gland.. 


\section{Introduction}

Polycyclic aromatic hydrocarbons (PAHs), particularly benzo[a]pyrene (B[a]P), are common pollutants in the environment (Caricchia et al., 1993, Magi et al., 2002), including the Adriatic coast, and of great concern for their toxicity, mutagenicity and carcinogenicity (Gomez-Mendikute et al., 2002) and consequently have been widely studied in aquatic ecotoxicology.

Bivalve molluscs bioaccumulate lipophilic organic pollutants such as B[a]P (Durand et al., 2002) and in these aquatic organisms in vivo and in vitro $\mathrm{B}[\mathrm{a}] \mathrm{P}$ biotransformation to primary metabolites (phenols, dihydrodiols, and mainly quinones) and conjugates has been widely demonstrated (Livingstone, 1998). This first step in the metabolism of PAHs was catalysed by cytochrome P450 (CYP) monoooxygenase (or mixed-function oxygenase) system (EC 1.14.14.1).

CYPs exist in multiple forms classified into families, subfamilies and individual members, that catalyse many reactions involved in both endogenous metabolism and oxidative metabolism of xenobiotics (Mansuy, 1998; Gonzalez, 2005). Families CYP1 to CYP4 are involved in the metabolism of xenobiotics (Nelson et al., 2004; Gonzalez, 2005), with the CYP1A subfamily being of major importance in all of vertebrate classes in the metabolism and detoxication/activation of PAHs and organochlorines (Teramitsu et al., 2000). Both these latter types of compounds in vertebrates bind to the aryl hydrocarbon receptor (AHR) leading to increased CYP1A expression/activity and increased toxicity by several mechanisms, including enhanced reactive oxygen species (ROS) production (Chae et al., 1993; Liu et al., 2001). Moreover vertebrate CYP2E1 is involved in the metabolism and activation of a large number of low molecular weight substances, such as aliphatic, aromatic and halogenated hydrocarbons (Guengerich et al., 1991), and it is one of the most active CYPs in ROS production (Gonzalez, 2005).

The CYP monooxygenase system and associated catalytic activities, such as BaP hydroxylase, are widely distributed throughout aquatic invertebrate taxa overall in the digestive gland, the main organ of xenobiotic metabolism (Solé and Livingstone, 2005) 
The CYP1A-like protein in mytilids has been implicated in the metabolism of B[a]P (Wootton et al., 1996 Canova et al., 1998). No complete CYP1A sequence has yet been detected in molluscs (Herron, 2004), indicating that the protein(s) responsible for $\mathrm{B}[\mathrm{a}] \mathrm{P}$ metabolism and/or recognised by fish anti-CYP1A (see above) likely belong to a different, possibly unique, CYP group.

Enhanced production of ROS, is thought to be an important mechanism of pollutant-mediated toxicity in aquatic organisms (Livingstone, 2001). An imbalance of ROS and other pro-oxidant production over antioxidant defences results in increased oxidative damage to unsaturated lipid, DNA and other key molecules, resulting in a condition of oxidative stress (Halliwell and Gutteridge, 1999). The extent of such damage is dependent on the effectiveness of the antioxidant defences (Michiels and Remacle, 1988), including the key antioxidant enzyme superoxide dismutase (SOD; EC. 1.15.1.1) (Halliwell and Gutteridge, 1999). CYP-catalysed metabolism of $\mathrm{B}[\mathrm{a}] \mathrm{P}$, resulting in ROS generation, (Sjölin and Livingstone, 1997), has been proposed as a pollutant-mediated mechanism of toxicity in molluscs (Livingstone, 2001). SOD is widely distributed in molluscs (Doyotte et al., 1997; Regoli et al., 1997), and changes in its activity and form have been proposed as a biomarker of pollutant-mediated oxidative stress (Livingstone, 2001; Orbea et al., 2002).

The main aim of this research was to study the response of $S$. inaequivalvis to short-term exposure to water-borne $\mathrm{B}[\mathrm{a}] \mathrm{P}$, in terms of i) total CYP content, ii) responses of putative CYP isoenzymes; and iii) response of SOD activity and expression. Additionally, the metabolite profile of digestive gland microsomal metabolism of $\mathrm{B}[\mathrm{a}] \mathrm{P}$ was determined in control animals to examine whether redox cycling quinones were major products.

The blood clam, Scapharca inaequivalvis is a species of bivalve mollusc of Indo-Pacific origin, known to be present in the Adriatic Sea region since at least 1972. It is an infaunal organism, living burrowed in sandy-muddy sediments, with some unusual physiological characteristics, including in particular haemoglobin-containing blood cells and a high tolerance to hypoxia/anoxia (Cattani and Vitali 1995). It is known to be exposed to PAHs, with levels in sediments in the region varying 
from 24 to 501 ng per g dry weight in coastal areas (Chioggia and Ancona) (Magi et al., 2002) and up to $557 \mathrm{ng}$ per g dry weight in harbours (Trieste) and river mouths (Caricchia et al., 1993).

The novelty was represented by the study and discussion of these global relationships among different detoxification and antioxidant systems in Scapharca inaequivalvis, lack in similar works, in fact to date most research on CYP responses in bivalves has been carried out on Mytilus sp., with relatively little known for other species (Peters and Livingstone, 2001).

The paper focuses on several aspects of $\mathrm{B}[\mathrm{a}] \mathrm{P}$ metabolism in an important species of mollusc that plays a crucial role in Adriatic ecological systems. Since the clam (Scapharca inaequivalvis) was introduced some $30 \mathrm{yr}$ ago it has been rapidly outcompeting native bivalves and in now the dominant species (Ghisotti and Rinaldi, 1976). The presence of red blood cells (RBCs), obviously determine a great advantage in resisting the main side effects of eutrophication (frequently in Northern Adriatic sea), so during cycles of normoxia and severe lack of oxygen, Scapharca activates fermentative pathways for supplementing ATP production at much lower $\mathrm{pO}_{2}$ than $\mathrm{RBC}$ lacking bivalves (de Zwaan et al., 1991).

This work provides a complete evaluation that considers the accumulated xenobiotic, P450 content and expression, and the antioxidant defence involved in radical production. No comparable studies have been conducted for Scapharca inaequivalvis therefore the result are discussed in relation to information available for other bivalve species.

\section{Materials and methods}

\subsection{Chemicals}

All the reagents used for the determination of $\mathrm{B}[\mathrm{a}] \mathrm{P}$ levels, total CYP content and SOD activity were obtained from Sigma Aldrich (USA), Roche Diagnostics (USA) and Merck \&Co (USA). Protein determination was performed with a Bio-Rad DC Protein Assay kit (USA). For electrophoresis and western blotting: minigels, specific buffers and the chromogenic immunodetection kit were purchased from Invitrogen (UK); polyvinylidene difluoride (PVDF) 
membranes were from Bio-Rad (USA); the polyclonal rabbit anti-rat Mn-SOD, rabbit anti-human $\mathrm{Cu} / \mathrm{ZnSOD}$ and rabbit anti-rat CYP 2E1 antibodies were obtained from Stressgen (CAN), and the polyclonal goat anti-rabbit CYP 1A1/1A2 was obtained by Oxford Biomedical Researches (USA); and CuZnSOD standard was from Sigma Aldrich (USA). HPLC (High Performance Liquid Chromatography) chemicals were from Merck or Packard UK and were HPLC or Scintran grade. Authentic $\mathrm{B}[\mathrm{a}] \mathrm{P}$ metabolite standards were obtained from the NCI Chemical Carcinogen Respository (Kansas City, USA).

\subsection{Animals}

Clams were collected in an uncontaminated area of Northern Adriatic Sea, by local fishermen using a hydraulic dredge dragged over the sandy sea bottom. After collection, animals were suspended in open baskets in wide aquaria with filtered sea water at a temperature of $17-18^{\circ} \mathrm{C}$ and at a salinity o $34 \%$, the sea water was pumped in from an inlet approximately $300 \mathrm{~m}$ offshore. Every second day, $50 \%$ of the water was changed. Bivalves were allowed to acclimatize to laboratory conditions for one week before their utilization in exposure experiments. Clams for microsomal $\mathrm{B}[\mathrm{a}] \mathrm{P}$ metabolism studies were collected separately and held in filtered sea water for a few days, without feeding, to clear gut contents, prior to dissection; digestive glands were removed as described below for the exposure experiment.

\section{3. $\mathrm{B}[\mathrm{a}] \mathrm{P}$ exposure and animal dissection}

Specimens of $4.5 \pm 0.4 \mathrm{~cm}$ shell length were put in tanks containing filtered seawater ( 4 animals/L) at a temperature of $17-18^{\circ} \mathrm{C}$. Because of its low solubility in water, $\mathrm{B}[\mathrm{a}] \mathrm{P}$ was first adsorbed to a solid phase constituted of celite ${ }^{\circledR} 545$ (Merck \& Co). B[a]P was added to celite as an acetone solution and the organic solvent subsequently evaporated by rotary evaporation. After drying, celite was added in a single administration to the sea water, to give a final $\mathrm{B}[\mathrm{a}] \mathrm{P}$ concentration of 0.44 $\mathrm{mg} / \mathrm{L}$, and maintained in suspension with the aid of a magnetic stirrer. Treated animals (not fed) were compared with controls maintained in the same experimental condition except for the absence of $\mathrm{B}[\mathrm{a}] \mathrm{P}$ bound to the added celite. 
Animals were sampled at $0,12,24$ and 36 hours of exposure. Two sets of animals were taken at each sampling time for biochemical and chemical analyses. Digestive glands from the first set of animals were immediately dissected out, damp-dried, frozen in liquid nitrogen and stored at $-70^{\circ} \mathrm{C}$, In order to have enough material for the biochemical analyses, a total of 18 clam were sampled for each experimental condition. Digestive glands from each condition were pooled (three pools/condition).

Analogous analyses of the $\mathrm{B}[\mathrm{a}] \mathrm{P}$ body-burden concentration were performed on whole tissues from a second set of 18 animals for each experimental condition (three pools/condition).

\subsection{Determination of tissue $\mathrm{B}[\mathrm{a}] \mathrm{P}$ levels}

All solvents were distilled before use. Solid phase extraction (SPE) was performed with Isolute ${ }^{\mathrm{TM}}$ (SI $500 \mathrm{mg} / 3.0 \mathrm{ml}$ ) cartridges obtained from International Sorbent Technology Ltd. (Hengoed, UK). A B[a]P standard (Min. 97\%, HPLC grade, Sigma) was used.

Analyses were carried out using a Kontron System Pump 325 ternary liquid chromatograph equipped with a $20 \mu$ l loop, combined with a Thermoquest FL3000 fluorescence detector. A Supelcosil LC-PAH $5 \mu \mathrm{m}$ column ( 250 x 4.6 mm I.D.) (Supelco, Bellefonte, PA, USA) was used. After defrosting, 20-30g of sample (corresponding to one pool constituted to 6 animal) were submitted to lipid extraction (Christie, 1982). The lipid fraction, after solvent evaporation, was submitted to the partition, cleanup and chromatographic analyses after Moret et al., (1999).

For BaP fluorescence determination, excitation (Ex) and emission (Em) were: $E x=268 \mathrm{~nm}, \mathrm{Em}=398$ $\mathrm{nm}$. The linearity and the quantification of the instrumental response were checked by injecting the $\mathrm{B}[\mathrm{a}] \mathrm{P}$ standard prepared in five different concentrations ranging from $20 \mu \mathrm{g} / \mathrm{L}$ up to $800 \mu \mathrm{g} / \mathrm{L}$. The recovery of $\mathrm{B}[\mathrm{a}] \mathrm{P}$ was of $80 \%$ and the $\mathrm{CV}$ (variation of coefficient) was of $7-8 \%$.

\subsection{Biochemical analyses}

Digestive gland subcellular fractions were prepared essentially as described in Livingstone (1988). All procedures were carried out at $4^{\circ} \mathrm{C}$. Frozen pooled digestive gland was homogenized with an Ultraturrax (or Potter-Elvehjem) homogenizer in 1:4 (w/v) homogenization buffer (20 mM Tris- 
$\mathrm{HCl} \mathrm{pH} 7.6,0.5 \mathrm{M}$ sucrose, $0.15 \mathrm{M} \mathrm{KCl}, 1 \mathrm{mM}$ EDTA). The homogenate and resulting supernatants were progressively centrifuged at $500 \mathrm{~g}$ x $30 \mathrm{~min}, 12,000 \mathrm{~g} \mathrm{x} 45 \mathrm{~min}$ and $100,000 \mathrm{~g}$ x $90 \mathrm{~min}$ to obtain the microsomal and cytosolic fractions. The mitochondrial and cytosolic fractions were combined together in the same ratio as in the original homogenate and used for the SOD determinations (activity measures and western blotting). The microsomal pellet was washed by resuspension in homogenization buffer and further centrifuged at $100,000 \mathrm{~g}$ x $30 \mathrm{~min}$. Finally the washed microsomal pellet was suspended in $10 \mathrm{mM}$ Tris- $\mathrm{HCl} \mathrm{pH} \mathrm{7.6,20 \%} \mathrm{w/v} \mathrm{glycerol,} 1 \mathrm{mM}$ EDTA to give a protein concentration of $\sim 5-10 \mathrm{mg}$ protein/ml. Microsomal samples were used for determination of total CYP content, CYP isoforms and $\mathrm{B}[\mathrm{a}] \mathrm{P}$ metabolism. If not used immediately, the microsomal samples were aliquotted into Cryovials and stored under liquid nitrogen $\left(-196^{\circ} \mathrm{C}\right)$, until required.

2.6. Cytochrome $\mathrm{P} 450$ content

Total CYP content was measured after Livingstone (1988) in a temperature-controlled UV/VIS Uvikon 941 spectrophotometer (Kontron Instruments). Spectra were measured in the range of 400 to $500 \mathrm{~nm}$ at $25 \pm 1{ }^{\circ} \mathrm{C}$, and total $\mathrm{CYP}$ calculated using an extinction coefficient of $91 \mathrm{mM}^{-1} \mathrm{~cm}^{-1}$ $\left(A_{450-490)}\right.$.

2.7. Superoxide dismutase activity assay

The activity of SOD was measured in a UV/Vis Beckman DU 530 spectrophotometer, temperaturecontrolled to $25 \pm 1^{\circ} \mathrm{C}$. SOD activity was determined with the xanthine oxidase-cytochrome c method according to Crapo et al. (1978). The Cu/Zn-containing form of SOD was assayed by the inhibitory effect of 1mM KCN on SOD activity (Fridovich, 1982).

\subsection{Protein assay}

Total soluble protein concentration was measured according to Lowry et al. (1951) by a Bio-Rad DC Protein Assay kit, using a microassay procedure and bovine serum albumin as the standard. The protein content was determined using 96-well microtiter plates. The extinction was read at $750 \mathrm{~nm}$ 
in a Labsystem MultisKan EX spectrophotometer. Values were reported as mg protein per $\mathrm{ml}$ and were used to normalize enzyme activity and expression.

\subsection{Electrophoresis and western blotting}

SDS-PAGE (Sodium Dodecyl Sulfate-Polyacrylamide Gel Electrophoresis) of different subcellular fractions, (section 2.5) were performed in an Invitrogen Xcell SureLock Mini-Cell using minigels (Bis-Tris gels) consisting of $12 \%$ running gel with MES [2-(N-morpholino)ethane sulfonic acid] running buffer at $\mathrm{pH}$ 7.3, under reducing conditions. Samples were added with LDS (lithium dodecyl sulphate) buffer and reducing agent $\left(0.5 \mathrm{M}\right.$ dithiothreitol) and heated for $10 \mathrm{~min}$ at $70^{\circ} \mathrm{C}$. Apparent molecular weights of immunopositive bands were determined from simultaneously run pre-stained molecular weight markers. Aliquots of partially purified Mn-SOD (obtained by gel chromatography using a Sephadex G-75 column, 1x90cm) from the bivalve mollusc $S$. inaequivalvis, and $\mathrm{Cu} / \mathrm{Zn}-\mathrm{SOD}$ from bovine erythrocytes, were loaded in the gels as standards to identify the two SOD isoforms. Samples were loaded to the gel in volumes corresponding to a protein content range of from 30 to $40 \mu \mathrm{g}$.

After electrophoresis, proteins were transferred for $1 \mathrm{~h}$ to polyvinylidene difluoride (PVDF) membranes in an Invitrogen Xcell SureLock Blot Modul using transfer buffer pH 7.2 (Bicine, bisTris, EDTA, chlorobutanol). After blotting, the PVDF membranes were treated with specific chromogenic western blot immunodetection kits. Blots were blocked for 45 min with concentrated casein solution in buffered saline solution and then incubated with the diluted primary specific antibody for $1 \mathrm{~h}$. To identify the SOD isoforms, rabbit polyclonal anti-Cu/Zn-SOD, diluted 1:10,000, and rabbit polyclonal anti-Mn-SOD, diluted 1:7,000 were used. CYP detection was carried out using goat polyclonal anti-CYP $1 \mathrm{~A} 1 / 1 \mathrm{~A} 2$, diluted 1:100 and by rabbit polyclonal antiCYP 2E1, diluted 1:2,500. Membranes were washed with a specific antibody wash solution and incubated with the secondary antibody solution consisting of alkaline phosphatase-conjugated antirabbit or anti-goat $\mathrm{IgG}$ for $45 \mathrm{~min}$. Blots were then visualised using chromogenic substrate containing 5-bromo-4-chloro-3-indolyl-1-phosphate (BCIP) and nitro blue tetrazolium (NBT). 
Immunopositive bands were semi-quantified by Quantity One Software (Bio-Rad) and results per unit protein were expressed in arbitrary units.

\subsection{Microsomal benzo[a]pyrene metabolism}

Microsomes were prepared from pooled frozen digestive glands as described in section 2.5. Assays and $\mathrm{B}[\mathrm{a}] \mathrm{P}$ metabolite and putative protein adduct analysis were performed on approximately $2 \mathrm{mg}$ of microsomal protein as described in Lemaire et al., (1993). After extraction of metabolites, putative protein adducts of $\mathrm{B}[\mathrm{a}] \mathrm{P}$ were quantified by repeated washing of precipitated microsomal material in methanol to remove loosely bound ${ }^{3} \mathrm{H}-\mathrm{B}[\mathrm{a}] \mathrm{P}$, dissolution in $1 \mathrm{M} \mathrm{NaOH}\left(40{ }^{\circ} \mathrm{C}\right.$ overnight), neutralization and counting of radioactivity (Lemaire et al., (1993).

\subsection{Statistical analyses}

Results were statistically analysed using one-way analysis of variance (ANOVA) followed by the Student's Neuman Keuls test for multiple comparisons using statistical package STAT software; only data obtained from microsomal benzo[a]pyrene metabolism analyses were compared by Student's t-test for independent samples with the same software. Values of $p<0.05$ was considered to be significant. Data are reported as means $\pm \mathrm{SD}$.

\section{Results}

\section{1. $\mathrm{B}[\mathrm{a}] \mathrm{P}$ concentration}

The results of $\mathrm{B}[\mathrm{a}] \mathrm{P}$ analyses performed on four specimen pooled whole tissues, sampled at 0 (control) 12, 24 and 36 hours of exposure are reported in Figure 1. Tissue B[a]P concentration levels were maximal after 12 hours of exposure $(1.78 \pm 0.06 \mathrm{ng} / \mathrm{g} \mathrm{ww})$, followed by a decrease at 24 and 36 hours of treatment, with levels of $1.1 \pm 0.5$ and $0.9 \pm 0.3 \mathrm{ng} / \mathrm{g} w w$ respectively. Statistical analyses showed that values after $12 \mathrm{~h}$ of exposure were significantly higher $(\mathrm{p}<0.01)$ than the 24 and 36 hour ones. In contrast, differences between $\mathrm{B}[\mathrm{a}] \mathrm{P}$ content at 24 and 36 hours were not 
256

257

258

259

260

significant $(\mathrm{p}>0.1)$. In control animals $\mathrm{B}[\mathrm{a}] \mathrm{P}$ was absent $(0.2 \mathrm{ng} / \mathrm{g}$ ww was the instrument detection limit).

\subsection{Cytochrome P450 content}

Total CYP concentration was measured in microsomes from pooled digestive glands. During the treatment with $\mathrm{B}[\mathrm{a}] \mathrm{P}$, a rapid increase of total CYP content was recorded, with levels ranging from $64 \pm 11 \mathrm{pmol} / \mathrm{mg}$ protein to $108 \pm 21 \mathrm{pmol} / \mathrm{mg}$ protein at 12 and 24 hours of exposure, respectively (Fig. 2), the latter value being significantly higher than the ones recorded both in control animals $(54 \pm 15 \mathrm{pmol} / \mathrm{mg}$ protein) and at 12 hours exposure $(\mathrm{p}<0.05)$. Total CYP content decreased at 36 hours $(87 \pm 11 \mathrm{pmol} / \mathrm{mg}$ protein) compared to 24 hours exposure but the levels were not significantly higher than the control samples.

\subsection{SOD activity}

The specific activities of $\mathrm{Cu} / \mathrm{Zn}-\mathrm{SOD}$ and Mn-SOD were measured in the combined mitochondrial and cytosolic fractions of the digestive gland (Fig. 3). Trends of increasing activity of both SOD isoforms were observed throughout the experiment. Mn-SOD activity showed a significant steady increase $(\mathrm{p}<0.05 ; \mathrm{p}<0.01)$ at 36 hours of exposure respect to the other experimental conditions,

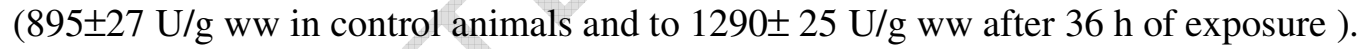

No significant differences were found in $\mathrm{Cu} / \mathrm{Zn}-\mathrm{SOD}$ activity during the $\mathrm{B}[\mathrm{a}] \mathrm{P}$ exposure compared to control animals with the other exposure conditions.

\subsection{Immunoblotting detection}

Western blots of digestive gland extract revealed single major bands for both Mn-SOD (Fig. 4) and $\mathrm{Cu} / \mathrm{Zn}$-SOD (Fig. 5), at the expected apparent molecular weights, indicating a high specificity of recognition of the cross-species antibodies. The Mn-SOD band had an apparent molecular weight of $26 \mathrm{kDa}$, corresponding to the monomeric form of the enzyme (Mn-SOD exists as a homotetramer with an individual subunit molecular weight of about $23 \mathrm{kDa}$ - Barra et al., 1984) (Fig. 4A). Results of densitometric analyses showed that the expression of Mn-SOD appeared not to change between 12 and 24 hours of exposure; however, slightly less Mn-SOD protein was seen at 36 hours of 
exposure compared to control animals ( $<<0.01$; Fig 4B). The $\mathrm{Cu} / \mathrm{Zn}-\mathrm{SOD}$ band had an apparent molecular weight of $16 \mathrm{kDa}$ (human $\mathrm{Cu} / \mathrm{Zn}-\mathrm{SOD}$ is homodimeric with a molecular weight of 31.2 $\mathrm{kDa}$ - Crapo et al., 1992) (Fig. 5A). The expression of the Cu/Zn-SOD band showed no variation ( $p>0.1$ ) during the time-course of the experiment (Fig. 5B).

Less specificity of recognition was seen with the cross-species antibodies for CYP1A1/1A2- and CYP2E1-immunopositive proteins in digestive gland microsomes as multiple bands were observed (Figs. 6 and 7). However, these included major bands in the apparent molecular weight range expected for CYPs, i.e. 40.6-50.5 kDa. Two major bands were found using anti-CYP1A1/1A2, which had apparent molecular weights of 50.5 and $40.6 \mathrm{kDa}$ (Fig. 6A). After densitometric analysis, the $50.5 \mathrm{kDa}$ band of CYP1A1/1A2-immunopositive protein was significantly more expressed after $36 \mathrm{~h}$ of $\mathrm{B}[\mathrm{a}] \mathrm{P}$ exposure with respect to the control and the other exposure sampling times $(\mathrm{p}<0.05-$ 0.01; Fig. 6B), whereas the $40.6 \mathrm{kDa}$ band showed the same expression in all conditions (data not shown). The anti-CYP2E1 recognized one immunopositive band present in all conditions with an apparent molecular weight of $49 \mathrm{kDa}$ (Fig. 7A). After the densitometric analyses of this band, no differences were found in the levels of CYP2E1-immunopositive protein between the control and the treated conditions (Fig. 7B).

3.5. Microsomal benzo[a]pyrene metabolism

The results of the in vitro metabolism of $\mathrm{B}[\mathrm{a}] \mathrm{P}$ by digestive gland microsomes of field animals are presented in Table 1. Metabolism both in the absence of NADPH (so-called 'NADPH-independent metabolism') and presence of NADPH (NADPH-dependent metabolism) showed a similar range of primary metabolites, including 7,8-dihydrodiol (diol); 1,6- , 3,6- and 6,12-quinones (diones); and at least two phenols that likely included the 3- and 9-phenols. The major metabolites formed in both cases were diones, comprising 89 to $90 \%$ of the total. Rates of production of total primary metabolites were inhibited $41 \%$ by the addition of NADPH due to a marked reduction in dione formation. In contrast, no differences were seen in diol formation, but a slight increase in 'phenol a' production occurred in the presence of NADPH $(\mathrm{p}<0.1)$. Tetrols were only detected in the absence 
of NADPH. In addition to primary metabolite formation, a substantial putative covalent binding of $\mathrm{B}[\mathrm{a}] \mathrm{P}$-derived metabolites to protein to form adducts was seen, equivalent to 48 to $55 \%$ of the rates seen for primary metabolites. Putative protein adduct formation was inhibited $49 \%$ in the presence compared to the absence of NADPH.

\section{Discussion}

Responses of the CYP-dependent monooxygenase system and antioxidant enzymes have been seen in bivalve and other molluscs after organic pollutant exposure (Peters and Livingstone, 2001).

\subsection{Bioaccumulation of $\mathrm{B}[\mathrm{a}] \mathrm{P}$}

Hydrophobic compounds such as $\mathrm{B}[\mathrm{a}] \mathrm{P}$ are readily taken up into the tissues of bivalve molluscs, the results seen in this study for S. inaequivalvis are comparable with those reported for other bivalves, both in laboratory and field exposures (Nasci et al., 2000; Porte et al., 2001), e.g. rapid accumulation of B[a]P was found in Mytilus edulis after six hours of water-borne B[a]P exposure (Durand et al., 2002). Differences also occur, very little bioaccumulation of B[a]P by the mussel Elliptio complanata being seen after five days of exposure (Gewurtz et al., 2002).

The decrease in whole body B[a]P levels in S. inaequivalvis between 12 and 36 hours is likely mainly due to depuration and/or biotransformation. Half-lives of loss of hydrophobic compounds such as B[a]P depend on many factors, including species and exposure period (Livingstone, 1991). Thus, $26 \%$ of B[a]P was lost from S. inaequivalvis between 12 and 24 hours after exposure compared to $0 \%$ for M. edulis for the same time period (Durand et al., 2002). Similarly, the halflife of loss of B[a]P from $S$. inaequivalvis was 24 hours (tissue B[a]P levels at 36 hours were $50 \%$ of those at 12 hours) compared to six to ten days for the clam Rangia cuneata following a one-day exposure period (Neff et al., 1976). In vivo biotransformation of $\mathrm{B}[\mathrm{a}] \mathrm{P}$ occurs in molluscs, but considerable species variation is reported (Magnusson et al., 2000; Varanasi et al., 1985).

A relationship has been determined for the dependence of in vivo biotransformation rates of hydrocarbons on tissue parent compound concentration (Livingstone, 1998). From this it can be 
calculated that a whole tissue $\mathrm{B}[\mathrm{a}] \mathrm{P}$ concentration of $6.75 \mathrm{pmol} \mathrm{g}^{-1}$ ww (i.e. $1.7 \mathrm{ng} \mathrm{g}^{-1}$ ww.) would produce an in vivo biotransformation rate of $0.0027 \mathrm{pmol} \mathrm{min}^{-1} \mathrm{~g}^{-1} \mathrm{ww}$, which compares well with the rate of $0.00243 \mathrm{pmol} \mathrm{min}^{-1} \mathrm{~g}^{-1} \mathrm{ww}$ required to reduce the $\mathrm{B}[\mathrm{a}] \mathrm{P}$ levels in $S$. inaequivalvis from 6.75 to 5.0 pmol g${ }^{-1}$ ww (i.e. $1.26 \mathrm{ng} \mathrm{g}^{-1} \mathrm{ww}$ ) over 12 hours. Thus the possibility exists that biotransformation may make a significant contribution to the reduction in $\mathrm{B}[\mathrm{a}] \mathrm{P}$ levels observed in S. inaequivalvis between 24 and 36 hours following exposure.

\subsection{Total CYP content and SOD activities}

Total CYP content of digestive gland microsomes was maximal after 24 hours of exposure, and double the levels of control animals, indicative of an inductive effect by B[a]P. Similar levels of increase in total CYP content with exposure to various PAHs have been seen for Mytilus sp. and the periwinkle Littorina littorea (Livingstone, 1991). The peak of total CYP (24 hours exposure) was not coincident with maximal $\mathrm{B}[\mathrm{a}] \mathrm{P}$ tissue levels (12 hours exposure), possibly due to the time required for full induction, or to the decrease in $\mathrm{B}[\mathrm{a}] \mathrm{P}$ levels caused by biotransformation.

With regard to CYP level/xenobiotic concentration, a correlation between variation in CYP content and tissue level of hydrocarbons was found in M. edulis and L. littorea (Livingstone, 1988).

During Phase I biotransformation the involvement of CYP and flavoprotein reductases leads to the production of ROS (Livingstone, 2001). Hepatic and other microsomes of many aquatic organisms have been shown to catalyse the monovalent reduction of xenobiotics, with the resultant generation of $\mathrm{O}_{2}^{-\bullet}$ and other ROS (Livingstone, 2001). In particular, digestive gland microsomes of M. edulis catalyse the redox cycling of PAH-quinones, including the 1,6-, 3,6- and 6,12-B[a]P-quinones, to produce $\mathrm{O}_{2}^{-\bullet}$ and $\mathrm{H}_{2} \mathrm{O}_{2}$ (Sjölin and Livingstone, 1997).

Protection against ROS is afforded by several antioxidant enzymes (included SODs studied in $S$. inaequivalvis) detected in many bivalve species (Orbea et al., 2002; Manduzio et al., 2004).

Mn-SOD activity showed a significant steady increase in digestive gland of $S$. inaequivalvis from control to 36 hours exposure; no significant differences were seen in $\mathrm{Cu} / \mathrm{Zn}-\mathrm{SOD}$ activity between control and other experimental conditions. Wenning and Di Giulio (1988) found a two-fold increase 
in total SOD activity in the freshwater bivalve Geukensia demissa exposed to 129 to $354 \mathrm{ppm}$ paraquat, although in this case the increase was transient, being maximal between 6 and 24 hours of exposure. The increase in SOD antioxidant enzyme activities in S. inaequivalvis with $\mathrm{B}[\mathrm{a}] \mathrm{P}$ exposure indicates biotransformation mechanisms that enhance ROS production. Shick and Dykens (1985) found in several tissues of bivalve Tridacna crocea the positive relationship between tissuespecific SOD activity and index of superoxide production $\left(\mathrm{R}^{2}: 0.759\right)$. Considering SOD activity as an indirect measure of $\mathrm{O}_{2}^{-\bullet}$ production ( $\mathrm{Yu}$ and Rengel, 1999), we found correlations between total CYP content and SOD isoform activities (Mn-SOD/CYP: $r=0.63 ; \mathrm{Cu} / \mathrm{Zn}-\mathrm{SOD} / \mathrm{CYP}: \mathrm{r}=0.96$ ), possibly indicating a role for CYP in putative $\mathrm{O}_{2}^{-\bullet}$ generation. Several studies have showed increase in SOD activity in digestive glands of mussels (Mytilus sp.) exposed to PAHs and PCBs (Porte et al., 1991), or collected from polluted sites (Porte et al., 1991). Cheung et al. (2001) observed an increase in SOD activity in digestive gland of the mussel Perna viridis that was positively correlated with $\mathrm{B}[\mathrm{a}] \mathrm{P}$ tissue concentrations, indicative again of $\mathrm{O}_{2}^{-\bullet}$ production related to xenobiotic in the tissue.

\subsection{Immunoblotting detection}

The expression of Mn-SOD protein in S. inaequivalvis did not parallel its enzyme activity during $\mathrm{B}[\mathrm{a}] \mathrm{P}$ exposure. The reasons for this divergent behaviour are not clear. Mn-SOD and its responses to pollutants have been little investigated in aquatic organisms, even though it plays a central role in cellular responses to oxidative stress and mitochondrial protection (Reed, 2001). Recent studies indicate that Mn-SOD is expressed in many cell types and tissues at relatively high levels and is highly regulated by various intracellular and environmental cues (Zelko et al., 2002), including cytokines and damaging cellular agents such as hyperoxia and chemical prooxidants (Halliwell and Gutteridge, 1999). The lack of correlation between Mn-SOD activity and expression, in the present study might be due to protein modification and/or associations to other proteins such as chaperonin (Manduzio et al., 2003). Probably SODs degeneration by ROS may have resulted in less active SOD isoforms that were still recognised by the antibodies used in the western blotting (Chan et al., 
1999). Also, several factors involved in the post-translation control of SOD enzyme biosynthesis have to be considered (Chan et al., 1999).

Again, differently from Mn-SOD, Cu/Zn-SOD activity was coherent with expression, which showed no change in $\mathrm{Cu} / \mathrm{Zn}$-SOD protein levels with $\mathrm{B}[\mathrm{a}] \mathrm{P}$ exposure. Manduzio et al. (2003) found changes in $\mathrm{Cu} / \mathrm{Zn}-\mathrm{SOD}$ isoform pattern in M. edulis exposed to copper, but no changes in total SOD activity. Several authors, despite considering the enzyme to be constitutively expressed, stated that its mRNA levels might be up- and down-regulated by several physiological conditions such as the presence of organic xenobiotics, metals and NO (Zelko et al., 2002). Cu/Zn-SOD have a widespread distribution in many type of cells, furthermore, it seems that cytoplasmatic $\mathrm{Cu} / \mathrm{Zn}$-SOD expression is stable and its activity is often considered to be an internal control for $\mathrm{Cu} / \mathrm{Zn}$-SOD gene expression (Zelko et al., 2002). With respect to $\mathrm{Cu} / \mathrm{Zn}-\mathrm{SOD}$, variable results have been seen with other aquatic animals exposed to PAHs (McFarland et al., 1999; Meyer et al., 2003).

Western blot analyses of CYP isoforms in digestive gland microsomes of S. inaequivalvis were performed using polyclonal antibodies for rabbit CYP1A1/1A2 and rat CYP2E1. Results showed a reasonable cross-reactivity between the mammalian anti-CYP antibodies and the CYP1A1/1A2and CYP2E1-immunopositive proteins in S. inaequivalvis. The putative CYP bands ranged in apparent molecular weight from 40.6 to $50.5 \mathrm{kDa}$ in agreement with Porte et al., (1995). Two major CYP bands were detected by anti-CYP1A/1A2 at 50.5 and $40.6 \mathrm{kDa}$, the expression of the former being increased at the end of the $\mathrm{B}[\mathrm{a}] \mathrm{P}$ exposure, whereas no differences were found in the latter.

The occurrence of a CYP1A like-protein in digestive gland of bivalve molluscs that can apparently be induced by PAHs and PCBs has been seen in a number of laboratory and field studies with Mytilus sp. (Livingstone et al., 1997; Peters et al., 1998). The conditions of exposure resulting in increased levels of digestive gland microsomal CYP1A-immunopositive protein vary, but the 36 hours $\mathrm{B}[\mathrm{a}] \mathrm{P}$ exposure observed for $S$. inaequivalvis compares well with the 4 days seen for $M$. galloprovincialis exposed to PCBs (Livingstone et al., 1997). Several literature data indicate a strong dependence of CYPs induction on tissue xenobiotic concentration and exposure time 
(Canova et al., 1998). In fish and other vertebrates, CYP1A induction is regulated through a ligandactivated transcription factor known as the Aryl Hydrocarbon Receptor (AHR) (Hahn, 2002). Relatively little is known of this mechanism in molluscs, but recently AHR homologs have been found in the bivalves Mya arenaria, Dreissena polymorpha and M. edulis (Wiesner et al., 2001). A high affinity of the inducing xenobiotic to AHR results in high CYP1A induction (Billiard et al., 2002). However, the observed responses, and the existence of AHR homologs, argue that an AHRdependent mechanism may exist in molluscs, and the response may have biomarker application (Peters and Livingstone, 2001).

A single major anti-CYP2E1 band of apparent molecular weight $49 \mathrm{kDa}$, unaffected by 36 hours exposure to B[a]P, was seen in digestive gland micosomes of $S$. inaequivavlvis,. In Mytilus sp., higher levels of CYP2E-immunopositive protein were seen in polluted compared to clean populations in the Venice Lagoon (Peters et al., 1998) and the UK (Shaw et al., 2000), but in the latter case only at one time of the year (May), indicating a seasonal regulation of gene expression. Additionally, unlike CYP1A-immunopositive protein, CYP2E-immunopositive protein was not elevated in M. galloprovincialis after 3 weeks transplantation to an industrially polluted site (Peters et al., 1998), indicating a slow response to PAHs, PCB and other pollutants. However, the absence of a response in S. inaequivalvis indicates that elevation of the CYP2E-immunopositive protein does not contribute to toxicity with $\mathrm{B}[\mathrm{a}] \mathrm{P}$ exposure.

\subsection{Microsomal benzo[a]pyrene metabolism}

Bivalve and other molluscan digestive gland microsomes show the unusual properties of a) CYPcatalysed monooxygenation in the absence of added NADPH (termed 'NADPH-independent' metabolism), and b) metabolism of B[a]P to predominantly diones (Livingstone, 1991). NADPHindependent metabolism has been seen in over twenty molluscan species for a variety of monooxygenation reactions (Livingstone, 1991; Solé and Livingstone, 2005). Metabolism of B[a]P to $70 \%$ or more diones, with the remaining metabolites comprising tetrols, diols and phenols, has been seen for Mytilus sp., Crassostrea virginicia and Cryptochiton stelleri (Livingstone, 1991; 
Lemaire et al., 1993; Michel et al., 1993). This is in contrast to microsomal metabolism of vertebrates, echinoderms, crustaceans and polychaetes which produce mainly diols and phenols (Livingstone, 1991). Results similar to the ones observed in other molluscs were obtained for $S$. inaequivalvis, which showed NADPH-independent metabolism of $\mathrm{B}[\mathrm{a}] \mathrm{P}$ to $90 \%$ diones. Putative protein adducts were also formed in the absence of added NADPH, as has been observed for Mytilus sp. (Lemaire et al., 1993). The inhibition of dione and putative protein adduct, but not diol or phenol, formation by added NADPH is consistent with results for Mytilus sp. (Livingstone, 1991). These results for Mytilus sp. led to the hypothesis that the CYP-catalysed metabolism of $\mathrm{B}[\mathrm{a}] \mathrm{P}$ may proceed by two pathways, namely one-electron oxidation leading to mainly dione and protein adducts, and two-electron monooxygenation leading to phenols (Livingstone, 1992). Despite conjugation by Phase II metabolism, substantial quantities of free B[a]P-diones are formed in vivo in M. galloprovincialis (Michel et al., 1995), indicating that B[a]P-dione-mediated ROS production, via redox cycling (Garcia Martinez and Livingstone, 1995), may be a significant mechanism of toxicity in whole animals.

\section{Conclusion}

Rapid uptake of $\mathrm{B}[\mathrm{a}] \mathrm{P}$ was followed by a decrease in levels in the tissues, which could have been due to depuration, but also to significant biotransformation. The presence of $\mathrm{B}[\mathrm{a}] \mathrm{P}$ resulted in increases in both total CYP (24 hours) and CYP1A-immunopositive protein (36 hours). The latter response was isoenzyme-specific as no change was seen in CYP2E-immunopositive protein. However, other unknown CYPs must also have been induced because maximum CYP1Aimmunopositive protein levels did not correspond with total CYP levels. Metabolism of $\mathrm{B}[\mathrm{a}] \mathrm{P}$ to redox-cycling diones, combined with elevation of total CYP levels, could have been mechanisms leading to enhanced ROS production and the concomitant increase in Mn-SOD activity. Overall, the results for S. inaequivalvis are consistent with those for other molluscs, and indicate that it may be a useful organism for ecotoxicological studies. 


\section{Acknowledgements}

466

467

468

469

470

471

472

473

474

475

476

477

478

479

480

481

482

483

484

485

486

487

Dr L D Peters for his highly instructional help in sample treatment and evaluation of microsomal CYP concentration.

The work was funded by grants ex-60\% Cattani-Serrazanetti. The microsomal B[a]P metabolism analysis was carried out at the NERC Centre for Coastal and Marine Sciences Plymouth Marine Laboratory.

\section{References}

Barra, D., Schinina, M.E., Simmaco, M., Bannister, J.W., Bannister, W.H., Rotilio, G., Bossa, F., (1984). The primary structure of 675 human liver manganese superoxide dismutase. J. Biol. Chem. $259,12595-12601$.

Billiard, S.M., Hahn, M.E., Franks, D.G., Peterson, R.E., Bols, N.C., Hodson, P.V., (2002). Binding of polycyclic aromatic hydrocarbons (PAHs) to teleost arylhydrocarbon receptors (AHRs). Comp. Biochem. Physiol. 133B, 55-68.

Canova, S., Degan, P., Peters, L.D., Livingstone, D.R., Voltan, R., Venier, P., (1998). Tissue dose, DNA adducts, oxidative DNA damage and CYP1A-immunopositive proteins in mussels exposed to waterborne benzo[a]pyrene. Mutat. Res. 399, 17-30.

Caricchia, A.M., Chiavarini, S., Cremisini, C., Martini, F., Morabito, R., (1993). PAHs, PCBs and DDE in the Northen Adriatic Sea. Mar. Pollut. Bull. 26, 581-583.

Cattani, O., Vitali, G., (1995). Effetti degli adattamenti biochimici alla carenza di ossigeno degli organismi marini sulle comunità bentoniche di aree eutrofizzate. Il caso dell'Adriatico NordOccidentale. Congresso: Evoluzione dello stato trofico in Adriatico: analisi degli invertebrati attuali e future linee di intervento, Marina di Ravenna, 28-29 settembre 1995, 101-112. 
Chae, Y.H., Yun, C.H., Guengerich, F.P., Kadlubar, F.F., El-Bayoumy, K., (1993). Roles of human hepatic and pulmonary cytochrome P450 enzymes in the metabolism of the environmental carcinogen 6-nitrochrysene. Cancer Res. 53, 2028-2034.

Chan, P., Liao, S.S., Hsu, C.T., Lee, Y.S., Brian, T., Kuo, J.S., Cheng, J.T., (1999). Superoxide dismutase gene expression and activity in the brain of spontaneously hypertensive rats and normotensive rats. Chin. Med. J. 112, 1119-1124.

Cheung, C.C.C., Zheng, G.J., Li, A.M.Y., Richardson, B.J., Lam, P.K.S., (2001). Relationships between tissue concentrations of polyciclic aromatic hydrocarbons and antioxidative responses of marine mussels, Perna viridis. Aquat. Toxicol. 52, 189-203.

Christie WW (1982) In: Lipid Analysis, 2nd edn. Pergamon Press, Oxford, England, 22-23.

Crapo, J.D., McCord, J.M., Fridovich, I., 1978. Preparation and assay of superoxide dismutases. Method. Enzymol. 53, 382-393.

Crapo, J.D., Oury, T., Rabouille, C., Slot, J.W., Chang, L-Y., (1992). Copper, zinc superoxide dismutase is primarily a cytosolic protein in human cells. Proc Natl Acad Sci USA 89, 1040510409.

De Zwaan, A., Cortesi, P., Van der Thillart, G., Roos, J., Storey, K.B., (1991). Differential sensitivity to hypoxia by two tolerant marine molluscs: a biochemical analysis. Mar. Biol. 111, 343351.

Doyotte, A., Cossu, C., Jacquin, M.C., Babut, M., Vasseur, P., (1997). Antioxidant enzymes, glutathione and lipid peroxidation as relevant biomarkers of experimental or field exposure in the gills and the digestive gland of the fresh-water bivalve Unio tumidus. Aquat. Toxicol. 39, 93-110.

Durand, F., Laurence, D., Peters, L.D., Livingstone, D.R., (2002). Effect of intertidal compared to subtidal exposure on the uptake, loss and oxidative toxicity of water-born benzo[a]pyrene in the mantle and whole tissues of the mussel, Mytilus edulis L. Mar. Environ. Res. 54, 271-274.

Fridovich, I., (1982). Measuring the activity of superoxide dismutase: an embarrassment of riches. In: Oberlay, L.W. (Ed), Superoxide dismutase. CRC Press, Boca Raton, Florida, Vol I, pp 69-77. 
514

515

516

517

518

Garcia Martinez, P., Livingstone, D.R., (1995). Benzo[a]pyrene-dione stimulated oxyradical production by microsomes of digestive gland of the common mussel, Mytilus edulis L. Mar. Env. Res. 39, 185-189.

Gewurtz, S.B., Drouillard, K.G., Lazar, R., Haffner, G.D., (2002). Quantitative Biomonitoring of PAHs Using the Barnes Mussel (Elliptio complanata). Arch. Environ. Contamin. Toxicol. 43, 497504.

Ghisotti, F., Rinaldi, E., (1976). Osservazioni sulla popolazione di Scapharca insediatasi in questi ultimi anni su un tratto di litorale romagnolo. Conchiglie 12, 183-185.

Gòmez-Mendikute, A., Etxeberria, A., Olabarrieta, I., Cajaraville, M.P., (2002). Oxygen radicals production and actin filament disruption in bivalve haemocytes treated with benzo(a)pyrene. Mar. Envir. Res. 54, 431-436.

Gonzalez, F.J., (2005). Role of cytochromes P450 in chemical toxicity and oxidative stress: studies with CYP2E1. Mutat. Res. 569, 101-110.

Guengerich, F.P., Kim, D.H., Iwasaki, M., (1991). Role of human cytochrome P-450 IIEI in the oxidation of many low molecular weight cancer suspects. Chem. Res. Toxicol. 4, 168-179,

Hahn, M.E., (2002). Aryl hydrocarbon receptors: diversity and evolution. Chem. Biol. Interact. 141, 131-160.

Halliwell, B., Gutteridge, J.M.C., (1999). Antioxidant defences. In: Free Radicals in Biology and Medicine, 3rd edition. Oxford University Press Inc, NY, pp 105-245.

Herron, K.D., (2004). Novel cytochrome P450 isoenzymes in the mussel Mytilus edulis planulatus and other marine invertebrates. PhD thesis, RMIT University, Australia.

Lemaire, P., Den Besten, P.J., O'Hara, S.C.M., Livingstone, D.R., (1993). Comparative metabolism of benzo[a]pyrene by microsomes of hepatopancreas of the shore crab Carcinus maenas L. and digestive gland of the common mussel Mytilus edulis L. Poly. Arom. Comp. 3, 1134-1138.

Liu, L., Bridges, R.J., Eyer, C.L., (2001). Effect of cytochrome P450 1A induction on oxidative damage in rat brain. Mol. Cell. Bioch. 223, 89-94. 
540

541

542

543

544

545

546

547

548

549

550

551

552

553

554

555

556

557

558

559

560

561

562

563

564

Livingstone, D.R., (1988). Response of microsomal NADPH-cytocrome c reductase activity and cytocrome P450 in digestive glands of Mytilus edulis and Littorina littorea to environmental and experimental exposure to pollutants. Mar. Ecol. Prog. Ser. 46, 37-43.

Livingstone, D.R., (1991). Organic xenobiotic metabolism in marine invertebrates. Ad. Comp. Environ. Physiol., Vol 7, Springer-Verlag, pp 45-185.

Livingstone, D.R., (1992). Persistent pollutants in marine invertebrates. In: Walker, C.H., Livingstone, D.R. (Eds.), Persistent pollutants in marine ecosystems. Pergamon Press, Oxford, pp. $3-34$

Livingstone, D.R., Nasci, C., Solé, M., Da Ros, L., O’Hara, S.C.M., Peters, L.D., Fossato, V., Wootton, A.N., Goldfarb, P.S., (1997). Apparent induction of a cytochrome P450 with immunochemical similarities to CYP1A in digestive gland of the mussel (Mytilus galloprovincialis L.) with exposure to 2,2',3,4,4',5'-hexachlorobiphenyl and Arochlor 1254. Aquat. Toxicol. 38, 205224.

Livingstone, D.R., (1998). The fate of organic xenobiotics in aquatic ecosystems: quantitative and qualitative differences in biotransformation by invertebrates and fish. Comp. Biochem. Physiol. 120A, 43-49.

Livingstone, D.R., (2001). Contaminant-stimulated reactive oxygen species production and oxidative damage in aquatic organisms. Mar. Pollut. Bull. 42, 656-666.

Lowry, O.H., Rosebrough, N.J., Farr, A.L., Randall, J., (1951). Protein measure with the folin phenol reagent. J. Biol. Chem. 193, 265-275.

Magi, E., Bianco, R., Ianni, C., Di Carro, M., (2002). Distribution of polycyclic aromatic hydrocarbons in the sediments of the Adriatic Sea. Environ. Pollut. 119, 91-98.

Magnusson, K., Ekelund, R., Inghebrigtsen, K., Granmo, A., Brandt, I., (2000). Tissue disposition of benzo(a)pyrene in the blue mussel (Mytilus edulis) and effect of algal concentration on metabolism and depuration. Environ. Toxicol. Chem. 19, 2683-2690. 
565

566

567

568

569

570

571

572

573

574

575

576

577

578

579

580

581

582

583

584

585

586

587

Manduzio, H., Monsinjon, T., Rocher, B., Leboulenger, F., Galap, C., (2003). Characterization of an inducible isoform of the $\mathrm{Cu} / \mathrm{Zn}$ superoxide dismutase in the blue mussel Mytilus edulis. Aquat. Toxicol. 64, 73-83.

Manduzio H, Monsinjon T, Galap C, Leboulenger F, Rocher B (2004) Seasonal variations in antioxidant defences in blue mussels Mytilus edulis collected from a polluted area: major contributions in gills of an inducible isoform of $\mathrm{Cu} / \mathrm{Zn}$-superoxide dismutase and of glutathione $\mathrm{S}$ transferase. Aquat Toxicol 70, 83-93.

Mansuy, D., (1998). The great diversity of reactions catalysed by cytochromes P450. Comp. Biochem. Physiol. 121C, 5-14.

McFarland, V,A., Inouye, L.S., Lutz, C.H., Jarvis, A,S., McCant, D.D., (1999). Biomarkers of oxidative stress and genotoxicity in livers of field-collected brown bullhead. Arch. Environ.

Contam. Toxicol. 37, 236-241.

Meyer, J.N., Smith, J.D., Winston, G.W., Di Giulio, R.T., (2003). Antioxidant defenses in killifish (Fundulus heteroclitus) exposed to contaminated sediments and model prooxidants: short-term and heritable responses. Aquat. Toxicol. 65, 377-395.

Michel, X., Cassand, P.M., Ribera, D.G., Narbonne, J-F., (1993). Metabolism of benzo(a)pyrene by microsomes from mussel digestive gland and sea bass liver. Poly. Arom. Comp. 3, 1071-1078.

Michel, X., Beasse, C., Narbonne, J-F., (1995). In vivo metabolism of benzo(a)pyrene in the mussel Mytilus galloprovincialis. Arch. Environ. Contam. Toxicol. 28, 215-222.

Michiels, C., Remacle, J., (1988). Use of the inhibition of enzymatic antioxidant systems in order to evaluate their physiological importance. Eur. J. Biochem. 177, 435-441.

Moret, S., Conte, L.S., Dean, D., (1999). Assessment of polycyclic aromatic hydrocarbon content of smoked fish by means of a fast HPLC/HPLC method. J. Agric. Food. Chem. 47, 1367-1371.

Nasci, C., Da Ros, L., Nesto, N., Sperni, L., Passarini, F., Pavoni, B., (2000). Biochemical and histochemical responses to environmental contaminants in clam, Tapes philippinarum, transplated to different polluted areas of Venice Lagoon, Italy. Mar. Environ. Res. 50, 425-430. 
Neff, J.M., Cox, B.A., Dixit, D., Anderson, J.W., (1976). Accumulation and release of petroleumderived aromatic hydrocarbons by four species of marine animals. Mar. Biol. 38, 279-289.

Nelson, D.R., Zeldin, D.C., Hoffman, S.M.G., Maltais, L.J., Wain, H.M., Nebert, D.W., (2004).

Comparison of cytochrome P450 (CYP) genes from the mouse and human genomes, including nomenclature recommendations for genes, pseudogenes and alternative-splice variants. Pharmacogenetics 14, 1-18.

Orbea, A., Ortiz-Zarragoitia, M., Solè, M., Porte, C., Cajaraville, M.P., (2002). Antioxidant enzymes and peroxisome proliferation in relation to contaminant body burdens of PAH and PCB in bivalve molluscs, crabs and fish from the Urdaibai and Plentzia estuaries (Bay of Biscay). Aquat. Toxicol. 58, 75-98.

Peters, L.D., Livingstone, D.R., (2001). Induction of molluscan cytochrome P450 monooxygenase system as a biomarker of organic pollution in environmental monitoring. In: Garrigues, P.H., Barth, H., Walker, C.H., Narbonne, J.F. (Eds.), Biomarkers in Marine Organisms. A Practical Approach. Elsevier Press, Amsterdam, pp. 1-28.

Peters, L.D., Nasci, C., Livingstone, D.R., (1998). Variation in levels of cytochrome P450 1A, 2B, 2E, 3A and 4A-immunopositive proteins in digestive gland of indigenous and transplanted mussel, Mytilus galloprovincialis in Venice Lagoon, Italy. Mar. Environ. Res. 46, 295-299.

Porte, C., Solè, M., Albaigés, J., Livingstone, D.R., (1991). Responses of mixed-function oxygenase and antioxidase enzyme system of Mytilus sp. to organic pollution. Comp. Biochem. Physiol. 100C, 183-186.

Porte, C., Lemaire, P., Peters, L.D., Livingstone, D.R., (1995). Partial purification and properties of cytochrome P450 from digestive gland microsomes of the common mussel, Mytilus edulis L. Mar Environ. Res. 39, 27-31.

Porte, C., Biosca, X., Sole, M., Albaigés, J., (2001). The integrated use of chemical analysis, cytocrome $\mathrm{P} 450$ and stress proteins in mussels to assess pollution along the Galician coast (NW Spain). Environ. Pollut. 112, 261-268. 
617

618

619

620

621

622

Reed, D.J., (2001). Mechanisms of chemically induced cell injury and cellular protection mechanisms. In: Hodgson, E., Smart, R.C., (Eds), Introduction to Biochemical Toxicology. Wiley, New York, pp. 221-253.

Regoli, F., Principato, G.B., Bertoli, E., Nigro, M., Orlando, E., (1997). Biochemical characterization of the antioxidant system in the scallop Adamussium colbecki, a sentinel organism for monitoring the Antarctic environment. Polar. Biol. 17, 251-258.

Shaw, J.P., Large, A.T., Chipman, J.K., Livingstone, D.R., Peters, L.D., (2000). Seasonal variation in mussel Mytilus edulis digestive gland cytochrome P4501A- and 2E-immunoidentified protein levels and DNA strand breaks (Comet assay). Mar. Environ. Res. 50, 405-409.

Shick, J.M., Dykens, J.A. (1985). Oxygen detoxification in algal-invertebrate symbioses from the Great Barrier Reef. Oecologia 66, 33-41.

Sjölin, A.M., Livingstone, D.R., (1997). Redox cycling of aromatic hydrocarbon quinones catalysed by digestive gland microsomes of common mussel (Mytilus edulis L.). Aquat. Toxicol. 38, 83-99.

Solé, M., Livingstone, D.R., (2005). Components of the cytochrome P450-dependent monooxygenase system and 'NADPH-independent benzo[a]pyrene hyroxylase' activity in a wide range of marine invertebrate species. Comp. Biochem. Physiol. 141C, 20-31.

Teramitsu, H., Yamamoto, Y., Chiba, I., Iwata, H., Tenace, S., Fujise, Y., Kazusaka, A., Akahori, F., Fujita, S., (2000). Identification of novel cytochrome P450 1A genes from five marine mammal species. Aquat. Toxicol. 51, 145-153.

Varanasi, U., Reichert, W.L., Stein, J.E., Brown, U.W., Sanborn, H.R., (1985). Bioavailability and biotrasformation of aromatic hydrocarbons in benthic organisms exposed to sediment from an urban estuary. Environ. Sci. Technol. 19, 836-841.

Wenning, R.J., Di Giulio, R.T., (1988). Microsomal enzyme activities, superoxide production, and antioxidant defenses in ribbed mussels (Geukensia demissa) and wedge clams (Rangia cuneata). Comp. Biochem. Physiol. 90C, 21-28. 
642 Wiesner, L., Powell, W.H., Karchner, S.I., Franks, D.G., Cooper, E.L., Kauschke, E., Hahn, 643 M.E., (2001). cDNA cloning of aryl hydrocarbon receptor (AHR) homologues in zebra

644

645

646

647

648

649

650

651

652

653 mussel (Dreissena polymorpha) and blue mussel (Mytilus edulis). In: Pollutant Responses in Marine Organisms (PRIMO 11), Plymouth, England.

Wootton, A.N., Goldfarb, P.S., Lemaire, P., O'Hara, S.C.M., Livingstone, D.R., (1996). Characterisation of the presence and seasonal variation of a CYP1A-like enzyme in digestive gland of the common mussel, Mytilus edulis. Mar. Environ. Res. 42, 97-301.

Yu, Q., Rengel, Z., (1999). Micronutrient deficiency influences plant growth and activities of superoxide dismutases in narrow-leafed Lupins. Ann. Bot-London 83, 175-182.

Zelko, I.N., Mariani, T.J., Folz, R.J., (2002). Superoxide dismutase multigene family: a comparison of the CuZn/SOD (SOD1), Mn-SOD (SOD2) and EC-SOD (SOD3) gene structures, evolution and expression. Free. Radic. Biol. Med. 33, 337-349. 


\section{TABLES}

Table 1 Metabolism of tritiated benzo[a]pyrene $\left({ }^{3} \mathrm{H}-\mathrm{BaP}\right)$ by digestive gland microsomes (pmol mg-

${ }^{1}$ protein; mean $\pm \mathrm{SD}$ ) of Scapharca inaequivalvis.

\section{Metabolite}

Tetrol

Unknown diol

7,8-diol

1,6-dione

3,6-dione

6,12-dione

Phenol a

Phenol b

Total diols

Total diones

Total phenols

Total metabolites

Putative protein adducts

\section{Without added NADPH}

(pmol mg-1 protein)

\section{With added NADPH}

(pmol mg-1 protein)

$$
5.1 \pm 4.5
$$$$
7.5 \pm 8.1
$$$$
7.2 \pm 6.9
$$

$81.3 \pm 3.3$

$81.0 \pm 9.6$

$90.6 \pm 8.1$

$$
5.4 \pm 1.5
$$$$
5.4 \pm 7.8
$$

$$
\begin{gathered}
14.7 \pm 5.1 \\
252.9 \pm 6.0 \\
10.8 \pm 9.0 \\
283.5 \pm 17.7
\end{gathered}
$$

$154.8 \pm 3.3$

$$
0 \pm 0
$$

$$
1.5 \pm 1.5
$$$$
3.3 \pm 2.7
$$

$$
42.0 \pm 3.3 * * *
$$

$52.2 \pm 6.3 * *$

$53.7 \pm 9.0 * * *$

$10.2 \pm 3.0 *$

$$
1.8 \pm 3.3
$$

$$
\begin{aligned}
4.8 & \pm 4.2 \\
147.9 & \pm 10.8 * * * \\
12.0 & \pm 5.1 \\
164.7 & \pm 15.6 * * *
\end{aligned}
$$

$79.2 \pm 5.7 * * *$

Metabolites formed over 30 minutes of incubation; retention times (min) under the specified chromatographic conditions were tetrol (5.0), unknown diol (9.6), 7,8-diol (14.6), 1,6-dione (21.8), 3,6-dione (23.6), 6,12-dione (26.4), phenol a (29.2) and phenol b (32.0); phenol peaks include 3hydroxy- and 9-hydroxy-B[a]P. Values are mean \pm SD (triplicates); comparison of metabolites formed with or without NADPH showed significant differences where $* \mathrm{p}<0.1, * * \mathrm{p}<0.05$ and $* * * \mathrm{p}<0.01$ 
1

2

3

4

5

6

7

8

9

10

11

12

13

14

15

16

17

18

19

20

21

22

23

24

25

26

27

9

.

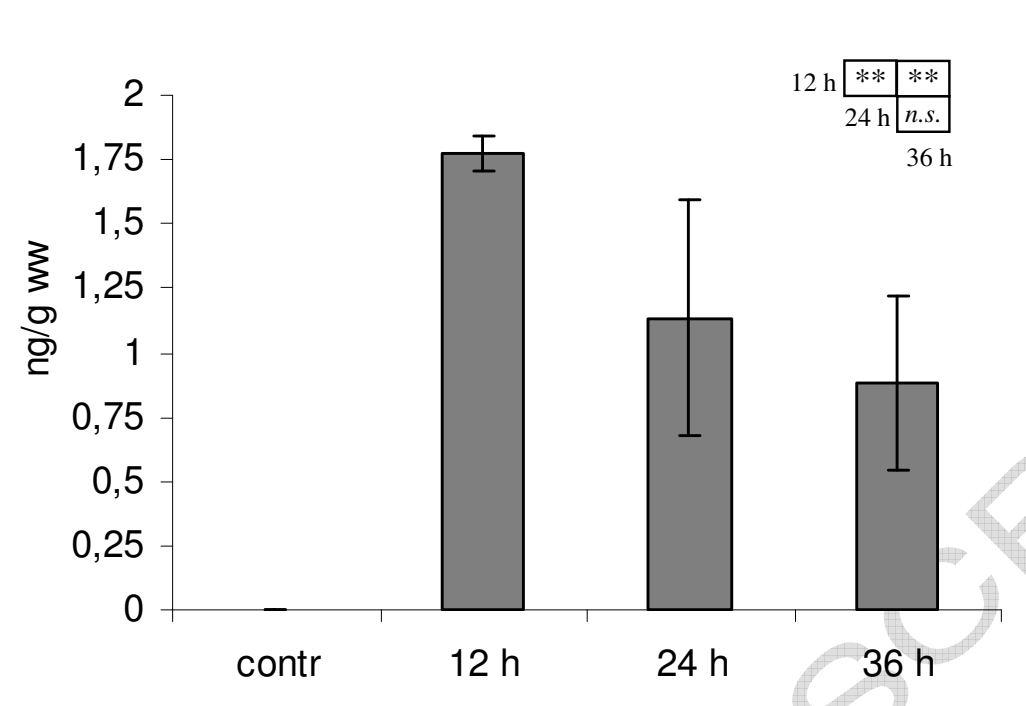

Figure 1

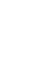

2

3

14

15

6

7

8

0

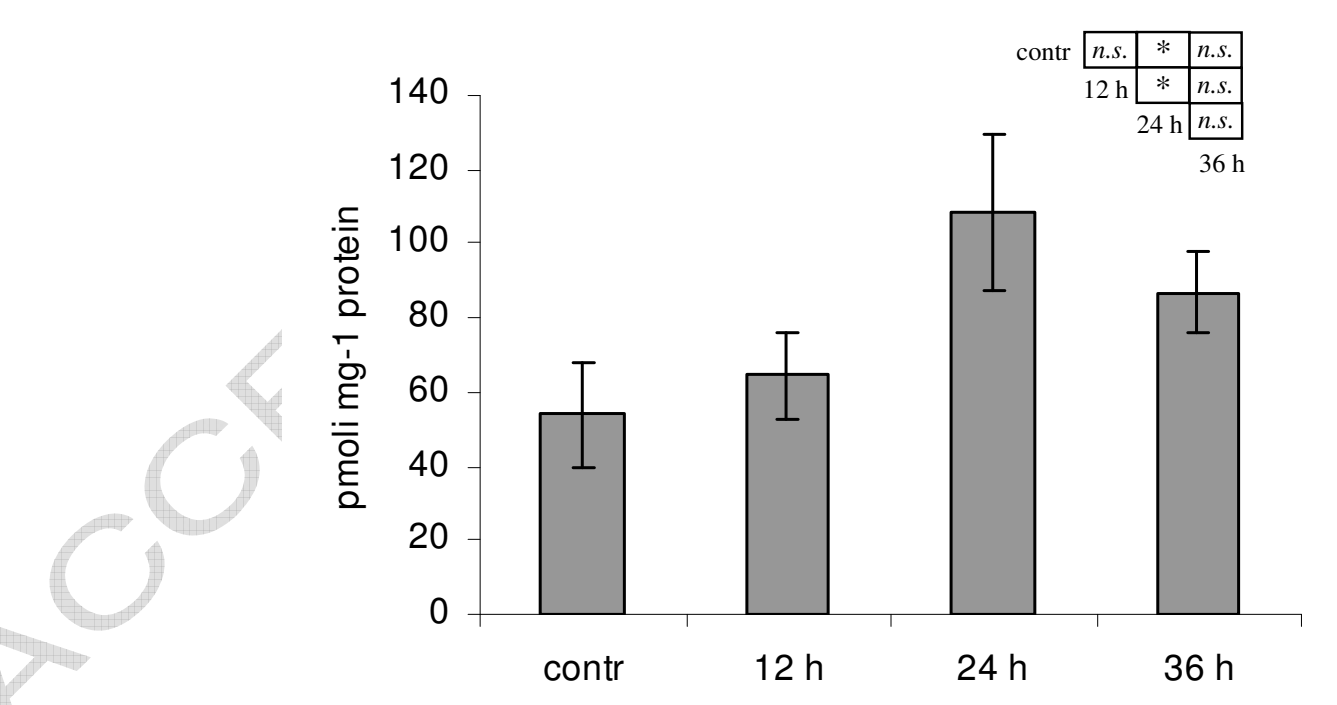

Figure 2 


29
30
31
32
33
34
35
36
37
38
$39 \quad$ Figure 3

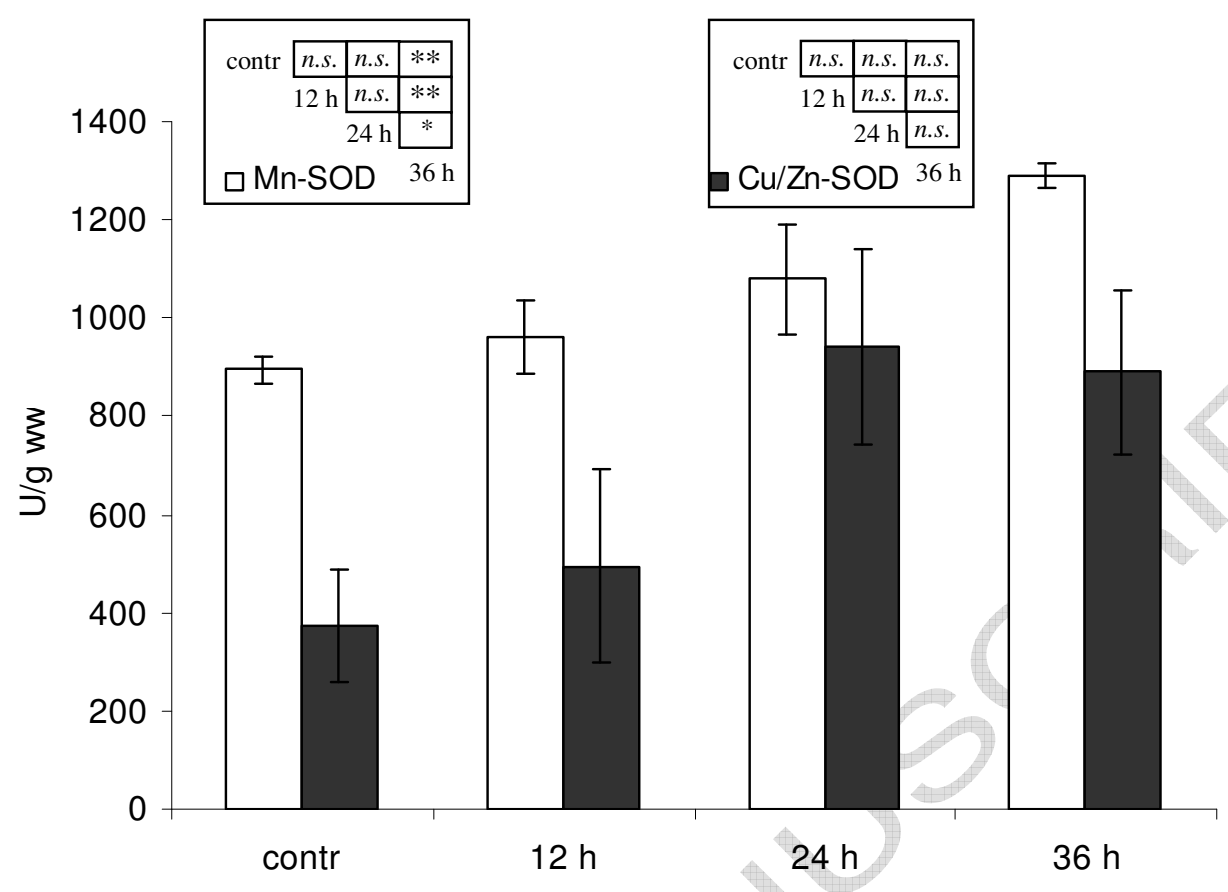

40

41

42

43

A

contr

$12 \mathrm{~h}$

24 h

$36 \mathrm{~h}$

Mn-SOD

44

45

46

B

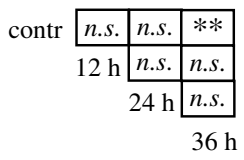

47

48

49

50

51

52

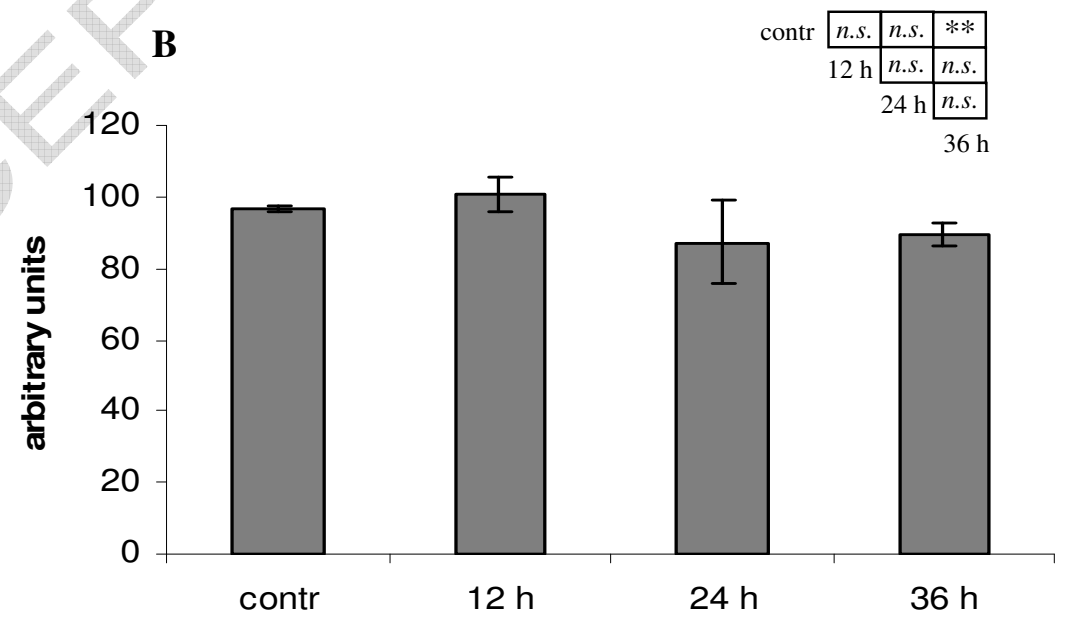

Figure 4 A ,B 


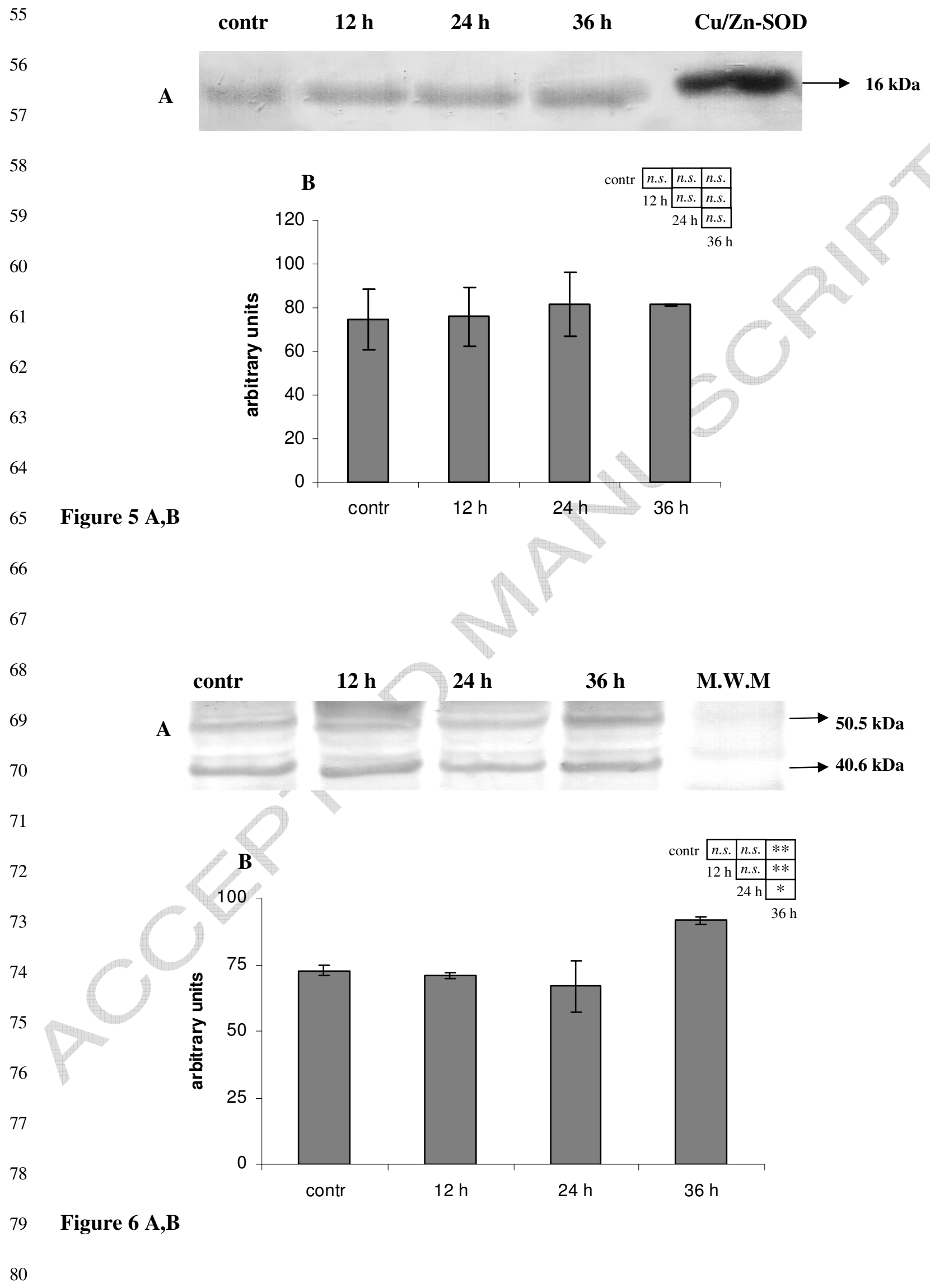


81

82

83

84

85

86

87

88

89

90

91

92

93

94

95

96

97

98

100

101

102

103

104

105

106

99

\section{Figure 7 A,B}

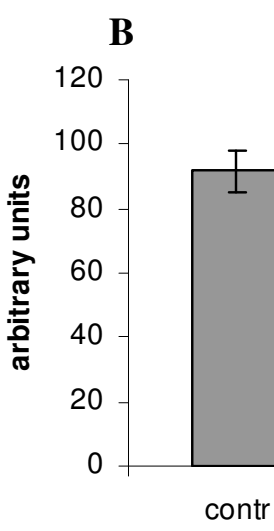

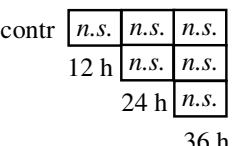

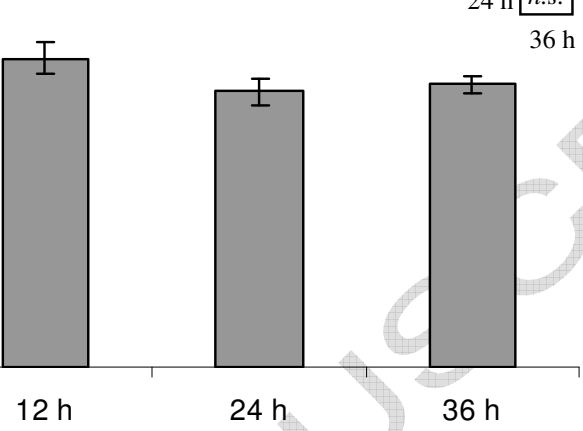

M.W.M

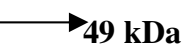

(2)

3

94

95

96

97

00

1

104 5 06 
Fig. 1. Scapharca inaequivalvis. B[a]P content in whole soft tissues in control animals (contr) and after 12, 24 and 36 hours of $\mathrm{B}[\mathrm{a}] \mathrm{P}$ exposure $(\mathrm{ng} / \mathrm{g}$ ww; mean $\pm \mathrm{SD}, \mathrm{n}=4)$. Asterisks: significant

Fig. 2. Total CYP content in digestive gland microsomes of Scapharca inaequivalvis in control animals (contr) and after 12, 24 and 36 hours of $\mathrm{B}[\mathrm{a}] \mathrm{P}$ exposure (pmol mg $\mathrm{m}^{-1}$ protein). Each histogram represents the mean \pm SD for three pools measured in triplicates. Asterisks: significant difference: ${ }^{*} \mathrm{p}<0.05$ Inset: significance of comparisons between experimental groups.

Fig. 3. $\mathrm{Mn}-\mathrm{SOD}$ and $\mathrm{Cu} / \mathrm{Zn}-\mathrm{SOD}$ activities in subcellular fraction (cytosolic/mitochondrial) of digestive gland of Scapharca inaequivalvis in control animals (contr) and after 12, 24 and 36 hours of $\mathrm{B}[\mathrm{a}] \mathrm{P}$ exposure $\left(\mathrm{U} \mathrm{mg}^{-1}\right.$ protein). Each histogram represents the mean $\pm \mathrm{SD}$ for three pools measured in triplicates. Asterisks: significant difference: $* * \mathrm{p}<0.01 ; * \mathrm{p}<0.05$. Inset: significance of comparisons between experimental groups.

Fig. 4. A. Western blots of Mn-SOD in subcellular fraction (cytosolic/mitochondrial) of digestive gland of Scapharca inaequivalvis in control animals (contr) and after 12, 24 and 36 hours of B[a]P exposure B. Densitometric analyses of blot expressed in arbitrary units. Each histogram represents the mean $\pm \mathrm{SD}$ for three pools measured in triplicates. Asterisks: significant difference: $* * \mathrm{p}<0.01$ Inset: significance of comparisons between experimental groups.

Fig. 5. A. Western blots of $\mathrm{Cu} / \mathrm{Zn}-\mathrm{SOD}$ in subcellular fraction (cytosolic/mitochondrial) of digestive gland of Scapharca inaequivalvis in control animals (contr) and after 12, 24 and 36 hours of $\mathrm{B}[\mathrm{a}] \mathrm{P}$ exposure B. Densitometric analyses of blot expressed in arbitrary units. Each histogram 
represents the mean \pm SD for three pools measured in triplicates. Inset: significance of comparisons between experimental groups.

Fig. 6. A. Western blots in digestive gland microsomes of Scapharca inaequivalvis incubated with anti-CYP1A1/A2, in control animals (contr) and after 12, 24 and 36 hours of B[a]P exposure B. Densitometric analyses of higher band (app. mol. wt. $50.5 \mathrm{kDa}$ ) expressed in arbitrary units. Each histogram represents the mean \pm SD for three pools measured in triplicates. Asterisks: significant difference: ${ }^{* *} \mathrm{p}<0.01 ;{ }^{*} \mathrm{p}<0.05$. Inset: significance of comparisons between experimental groups.

Fig. 7. A. Western blots in digestive gland microsomes of Scapharca inaequivalvis incubated with anti-CYP2E1 in control animals (contr) and after 12, 24 and 36 hours of B[a]P exposure B. Densitometric analyses of blot expressed in arbitrary units. Each histogram represents the mean \pm SD for three pools measured in triplicates. Inset: significance of comparisons between experimental groups. 